\title{
ROPN1 wt Allele
}

National Cancer Institute

\section{Source}

National Cancer Institute. ROPN1 wt Allele. NCI Thesaurus. Code C143009.

Human ROPN1 wild-type allele is located in the vicinity of 3q21.1 and is approximately 23

$\mathrm{kb}$ in length. This allele, which encodes ropporin-1A protein, is involved in sperm

capacitation. Aberrant expression may be associated with neoplastic disease. 